DOI: $10.17516 / 1997-1370-0645$

УДК $125,215,572$

\title{
The Dialogue between Theology and Science as an Open-Ended Hermeneutics of the Human Condition
}

\author{
Alexei V. Nesteruk* \\ University of Portsmouth \\ Portsmouth, Lion Gate Building \\ Russian Christian Humanitarian Academy \\ St. Petersburg, Russian Federation
}

Received 06.02.2019, received in revised form 25.07.2020, accepted 10.08.2020

\begin{abstract}
This paper represents a direct continuation and development of my stance on the sense of the dialogue between theology and science as it is seen through the eyes of phenomenological philosophy and its extension towards theology. I further interpret the paradoxical position of humanity in the world (being an object in the world and subject for the world) to be the cause in the split between science and theology. Since, according to modern philosophy, no reconciliation between two opposites in the hermeneutics of the subject is possible, the whole issue of the facticity of human subjectivity as the sensebestowing centre of being acquires theological dimensions, requiring new developments in both theology and philosophy. The intended overcoming of the unknowability of man by himself, tacitly attempted through the "reconciliation" of science and theology (guided by a purpose to ground man in some metaphysical substance), is not ontologically achievable, but demonstrates the working of formal purposefulness (in the sense of Kant). Then the dialogue between theology and science can be considered as a teleological activity without a purpose representing never-ending hermeneutics of the human condition.
\end{abstract}

Keywords: creation, dialogue, hermeneutics, human condition, man, philosophy, science, subject, theology.

This publication was made possible through the support of a grant "PH Philosophy In Neopatristics: New Figures And New Interpretations" from The National Science Centre, Poland (DEC-2018/31/B/HS1/01861).

Research area: philosophy of science and technology.

Citation: Nesteruk, A.V. (2020). The dialogue between theology and science as an open-ended hermeneutics of the human condition. J. Sib. Fed. Univ. Humanit. Soc. Sci., 13(8), 1338-1355. DOI: 10.17516/1997-1370-0645.

\footnotetext{
(C) Siberian Federal University. All rights reserved

* Corresponding author E-mail address: alexei.nesteruk@port.ac.uk ORCID: 0000-0001-6318-7907
} 


\section{Introduction:}

Man's Unknowability at the Inception of the Dialogue between Theology and Science

This paper represents a direct continuation and development of my stance on the sense of the dialogue between theology and science as it is seen through the eyes of phenomenological philosophy appropriated theologically (Nesteruk, 2018). Summarising our previous discussion of formulating the difference in the modi of the given in the natural sciences and theology, we have established that it amounts to the difference in the underlying ontology in the sciences (physical substance and biological formations) versus ontology of events (in theology), that is modi of phenomenality of that which is given within the structures of subjectivity. We have pointed out that in spite of the explicitly ontic features of theological propositions (as distinct from the ontologically rooted natural sciences), the very ontic needs to have an ontological basis (as a corporeal basis of a subject), whereas the ontological condition must be elucidated ontically through the structural path of its constitution by the subject. Thus the strict demarcation between theology and science on the basis of the opposition between ontic and ontological can hardy be achieved, contributing to the two-fold argument that a naïve positing of experience of the Divine outside the material conditions of the possibility of its expression, represents de facto faith without reason (whose existential and soteriological meaning remains obscure), whereas, at the same time, any physical reductionism in the constitution of humanity also fails without an appeal to theology of humanity's creation. The mediation between theology and science does not represent any metaphysical necessity but represents events of life, that is those dimensions of the human will and reason that cannot be deduced on the grounds of causality pertaining to the world. The facticity of the dialogue points to the fact that it represents the event-like phenomenon related to life's self-affectivity, so that its interpretation demands a philosophy that deals with the phenomenon of man as "event" of Life, the phenomenon that has a "meta-onto- logical" status, ordaining and justifying the very possibility of the philosophical as well as scientific knowledge of the world (Nesteruk, 2018). However, this "event of life", or, simply saying, the human phenomenon, being given to humanity, does not receive any further elucidation by man himself. The self-imposed question "What is man?" remains unanswered. Seen from this standpoint, all human activities, including those of science, as well as religious experience, originate in one and the same man in the conditions that this very man does not understand its own essence. Then both theology and science, as well as the dialogue between them, are functioning in the conditions of man's self-incomprehensibility. The sciences and religions are efficacious on the level of phenomena since they describe the facticity of life and explicate the sense of humanity through never-ending hermeneutics of the world. In a way, human activities give a witness to that which is unknowable in man contributing to a view of humanity as an "infinite task" for itself. By quoting $\mathrm{K}$. Jaspers, "We cannot exhaust man's being in knowledge of him, we can experience it only in the primal source of our thought and action. Man is fundamentally more than he can know about himself (Jaspers, 1954: 63, 66)." The sciences, philosophy and theology, all, pose questions to man about man himself that cannot lead to any definitive answer, thus provoking further questions (Moltmann, 1974: 2). Correspondingly the dialogue between theology and science, as particular modus of the human enquiry in the nature of things, contributes to further explication of the riddle of man with no aim of creating any metaphysical concept of man. The seeming dualism in comprehension of reality, either on the grounds of the sciences or through theological insights, explicates the dualism in the human condition between being and having: "We are, but we do not possess ourselves" (Plessner, 1961: $7)$, that is we are, but it is not us who created us. One can say that man has its own "I" as a co-participant of the infinite all-embracing being; however, it is because of the infinite character of such a communion with being that man cannot comprehend the sense of this 
communion's contingent givenness. As the sciences explicate the modus of "we are", that is the outward way of our existence as things (objects), they do not explain as to "why we are?", that is, why humanity is given to itself in such a way that the detection of the "we are" is possible at all. The drama of not being able to create himself is transferred by man to the cosmological scale when man is not being able to understand his place in the universe. ${ }^{1}$ Being groundless in the universe humanity does not have its own home not only in the sense of space, but also in the sense of the laws which it cannot control. ${ }^{2}$ Theology clarifies this issue of man not being able to possess himself by transforming it to the issue of participation in and communion with that which escapes the limits of metaphysical definitions.

The sciences play a twofold role in comprehending and formulating the sense of man's unknowability and groundlessness in the universe. It is science that makes it possible to bring on board outward aspects of man's unknowability through its insignificance in the physical universe. Without a scientific refinement of the predicaments of the human condition man would not be able to understand the scale of its epistemological significance for comprehending the universe and developing an articulated capacity of longing for the ultimate ground of its existence either in the world or beyond it. The ontological groundlessness of humanity is

\footnotetext{
Not dwelling long on the sense of this claim, but referring to a common knowledge of our insignificance in vast space portrayed by modern cosmology, we nevertheless quote $\mathrm{S}$. Frank, invoking a rather nostalgic description of the cosmic homelessness as a loss of the "motherland": "Contrary to deceptive appearances which man had trusted for thousands of years, his native abode, the earth, proved to be not the centre of the universe, but a mere speck, a part of a planetary system which itself was only an insignificant appendage of one of the innumerable stars lost in boundless space" (Frank, 1965: 190191)

2 In E. Fromm's words "He [man] is set apart while being a part; he is homeless, yet chained to the home he shares with all creatures. Cast into the world at an accidental place and time, he is forced out of it, again accidentally. Being aware of himself, he realises his powerlessness and the limitations of his existence. He visualises his own end: death. Never is he free from the dichotomy of his existence: he cannot rid himself of his mind, even if he should want to; he cannot rid himself of his body as long as he is alive..." (Fromm, 1967: 40).
}

exactly that intrinsic part of the human condition which provokes humanity for searching grace or "blessing" for its existence from that which is beyond the world and man himself.

The predisposition of transcending the sphere of the unconcealed relies on participation and communion with that which is beyond the visible and sensible. This transcending, even if it is not initiated by the sciences, is reactivated in man and made existentially dramatic through cooperation with the sciences. One cannot assert that the sciences are paving the way to a theological apprehension of the world, but at least one finds them refining the delimiters of the human condition, turning to a theological looking for the sense of existence. It is in this sense that the unknowability of man by himself, endorsed by scientific knowledge, becomes a factor of engaging with theology through abandoning any straightforward attempts to overcome this unknowability on the grounds of metaphysical concepts. The implicit hope and longing for overcoming the unknowability of man by himself, present in the modern sciences and some branches of philosophy, forms a hidden purpose implanted in the core of the human condition. This purpose is to acquire "home" in being, to ground man in that which he always transcends. This purpose is not ontologically achievable ${ }^{3}$, so that the whole process of knowledge is driven by this purpose only formally, that is as a teleological activity without a material purpose. ${ }^{4}$ The latter implies that the "reconciliation" between science and

\footnotetext{
"If he [man] ever finally got 'behind himself', and could establish what was the matter with him, nothing would any longer be the matter with him, but everything would be fixed and tied down, and he would be finished. The solution of the puzzle what man is would then be at the same time the final release from being human" (Moltmann, 1974: 2).

4 The terminology of formal purposiveness originates in Kant's "Critique of Judgement" and can briefly be defined, using his words : "[] An object, or state of mind, or even an action is called purposive, although its possibility does not necessarily presuppose the representation of a purpose, merely because its possibility can be explained and conceived by us only so far as we assume for its ground a causality according to purposes, i.e. in accordance with a will which has regulated it according to the representation of a certain rule" (Kant, 1951: 55) (Emphasis added)).
} 
theology could not be achieved so that the dialogue between theology and science can be considered as a teleological activity without a material purpose. Theologically, this activity could be understood as a mediation between moral divisions between his sense of creaturehood in the midst of the physical world and, at the same time, his being in communion with that which is beyond this world.

\section{Paradox of Subjectivity and the Dialogue between Theology and Science}

The unknowability of man by himself can easily be explicated through the so-called paradox of subjectivity ${ }^{5}$ whose concise formulation is: "We can describe the relations between subject and world as purely intentional relations as opposed to (objective) spatial, temporal, and causal relations. We can appeal to the distinction between belonging to the world of objects and being a condition of the possibility of the world of objects (as meaning). Perhaps the broadest terms for these relations would be the transcendental relations and the part-whole relation" (Carr, 1999: 116), or "It is necessary to combine the recognition of our contingency, our finitude, and our containment in the world with an ambition of transcendence, however limited may be our success in achieving it" (Nagel, 1986: 9).

The paradox, as co-existence of two attitudes to hermeneutics of the subject appears to be a structural element of the human subjectivity in general. Self-givenness and self-affectivity of "the subject" implies the question of facticity of consciousness which is missing from any articulations of the world. As was expressed by M. Merleau-Ponty, “...consciousness attributes this power of universal constitution to itself only if it ignores the event which provides its infrastructure and which is its birth. A consciousness for which the world 'can be taken for granted', which finds it 'already constituted' and present even in consciousness itself, does not absolutely choose

\footnotetext{
The formulations of the paradox are abundant. See e.g. (Kant, 1959: 260); (Husserl, 1970: 179); (Merleau-Ponty, 1982: 71-72); (Scheler, 1994: 160) etc. The review of different formulations of the paradox can be found in (Nesteruk, 2015: 136-161). See also (Carr, 1999).
}

either its being or its manner of being." ${ }^{6}$ It is because of the inexplicability of facticity of consciousness in metaphysical terms, it can be considered as "event" , event of existence of man. The temptation to find that missing foundation of its own realization in existence leads consciousness to transcendence in a theological direction, which exceeds the scope of philosophy, but, at the same time, extends philosophy towards appropriation of those realities which escape the phenomenality of objects. ${ }^{8}$ Then the paradox of subjectivity cannot have metaphysical explanation and falls under rubrics of event, that is something as given with no recourse to its possible metaphysical justification. In this case, the reconciliation of the terms in the paradox is equivalent to the elucidation of its very appearance in the subject, that is appearance of a personal subject, which is treated as event in the sense that no metaphysical explanation for existence of this subject is possible. Theology inevitably enters the discourse for, as we argued before, events are a "natural" domain of theology (Nesteruk, 2018). The problem of origin of the paradox

6 (Merleau-Ponty, 1962: 453) (emphasis added). As a matter of analogy one can quote B. Carr who comments on a similar situation in physics whose picture does not contain that same consciousness which generates the content of physical theories: "That physics has little to say about the place of man in the universe is perhaps not surprising when one considers the fact that most physicists probably regard man, and more generally consciousness, as being entirely irrelevant to the functioning of the universe" (Carr, 1998: 152).

7 Event can be described as the consummation of that, whose essence did not give the possibility of its foreseeing as if one could foresee the inconceivable impossible from the perspective of the conceivable possible (that is from within metaphysics with its principle of causality). See details on phenomenology of events in (Romano, 1998). A careful distinction of phenomenality of objects and phenomenality of events is made in (Marion, 2010: 243-308).

8 In general the term "phenomenality" describes the quality or state of a phenomenon. For example phenomenality of mundane things corresponds to their being perceptible by the senses or through immediate experience. This constitutes the notion of the phenomenal world, as the world of visible, empirical phenomena. One can talk about phenomenality of objects as entities being constituted according to the rubrics of "I think", so that such a phenomenality can be described in four rubrics: quantity, quality, relation and modality. The phenomenality of objects is different from the event-like manifestations, whose phenomanlity cannot be reduced to the stated four rubrics and where there is the excess of intuition over the discursive faculty. 
is reduced to the existence of the pre-predicative world, the life world, which in its sheer givenness is not reducible to anything in the natural world. Its interpretation proceeds from the theology of creation of life connoting with the Life understood as Divine Being. In words of M. Henry "I am not only for myself, i.e. this individual appearing in the world, a thing among things, a man among men.... In order to relate everything to oneself, one must first of all be this Self to whom everything is related, one must be able to say I am me. But the point is that this I am me is not at all originary... A Self such as that of man, a living transcendental Self - such a Self is only ever to be found in the 'Word of life' of the first letter of John, whom Paul describes as a 'First Born among many Brothers' (Romans, 8: 28-30)" (Henry, 2003: 104). In other words, the transition from the philosophical paradox to its theological sense can only be made by reducing the facticity of the paradox to the impossibility of its metaphysical description, that is to "event", manifesting God's creation of that which is metaphysically impossible (and hence unexplainable).

Theologians of the past expressed the paradox in terms explicitly containing a reference to that which is beyond the world, that is to the fact that the paradox explicates the condition of creaturehood. In his Epistles to Romans apostle Paul recapitulates man's paradoxical created condition by contrasting his serving to God's Law with his mind, and serving to the law of sin with his unspiritual nature (Rom, 7: 25). Maximus the Confessor advocated that God's image in man made him capable to mediate between moral divisions in himself and in creation in general, for example between the sensible (visible universe) and intelligible (invisible (for example an image of the world's wholeness in consciousness)): "As a compound of soul and body he [man] is limited essentially by intelligible and sensible realities, while at the same time he himself defines [articulates] these realities through his capacity to apprehend intellectually and perceive with his senses." " The Russian philosopher V. Soloviev ex-

\footnotetext{
9 Maximus the Confessor, Ambigua 10:26, PG 91, 1153B
} [ET: (Palmer, Sherrard, and Ware, 1986: 277)]. plicitly referred to God in his description of the human ambivalent condition: "Man comprises in himself all possible oppositions, all of which are reduced to one great opposition between the unconditional and conditional, or between the absolute and eternal being, and a transient phenomenon, an illusion. Man is deity and nothing at the same time" (Soloviev, 1989: 113). Another Russian philosopher and theologian V. Nesmelov expressed the paradox in different words: "all particular contradictions of thought and life arise from man's aspiration to fulfil the ideal image of the unconditional in the necessary boundaries of the external conditions" (Nesmelov, 1905:246); and "In knowledge of ourselves we know truly, that although our own person exists only in the necessary conditions of the physical world, by its nature it manifests not the world, but the true essence of the very Infinite and Unconditional" (Nesmelov, 1905: 269).

Now it is reasonable to pose a question on whether the impossibility of metaphysical explication of the paradox of subjectivity (that is unknowability of man) characterises something fundamental in the human condition which as such represents an element of its constitution in reflection. The philosophical impasse here may be elucidated through an appeal to theological anthropology relating the present human condition to the event of the Fall. In other words, the question can be posed like this: does the paradox of subjectivity in its outward formulation manifests the essence of that which represents a consequence of the event of transgression from union with God granted to the first man at the moment of his creation (implying that the first man wan knowable to himself)? If this would be true indeed, the consequence for our topic would be also manifesting and conclusive: the dichotomy between a scientific and theological vision of the world would originate in the Fall and the very telos of reconciliation between them can be treated as the healing and redemption of sin which ultimately would resolve the paradox and thus unified theology and science. In addition to such a conclusion one could argue that the split between science and theology encapsulates that characteristic feature of the post-lapserian condition of man and the world 
which a contemporary Greek Orthodox thinker C. Yannars emphatically described in terms of "evil". According to Yannaras, the paradox of subjectivity is a particular form of explication of "evil":

"All the laws of nature, the fundamental constancies of the natural world, its 'arbitrary' arithmetic values, constitute a single holistic phenomenon that tends organically from the outset toward the creation of conditions for its self-knowledge, that is to say, for intelligent life....And yet the way nature operates within the conditions prevailing on earth also manifests in a parallel fashion an autonomy (a mechanistic 'indifference') with regard to the intelligent existence of the human subject, its creative uniqueness and otherness... In this autonomy of nature, we human beings see a challenging 'absurdity' (a violation of our own rational conception of meaning in the world), an absurdity that we can only characterize as evil" (Yannaras, 2012: 16).

Yannaras' reading of the paradox through his understanding of man (as a creature longing for immortality but facing a defeat by the laws of nature) (Yannaras, 2011), contributes to the longstanding discussion of the paradox by philosophers, qualifying it as an expression of the basic anxiety of humanity in the world, its despair and non-attunement to the world, depriving man of understanding of the sense of existence. ${ }^{10}$ Can thus the paradox of subjectivity (implied in Yannaras' quote) be treated as a definition of "evil", related to the human incomprehension of his own condition, that is to the condition after the Fall? Or the notion of "evil", invoked by Yannaras, has a sense independent from the Fall and inherent in the condition of creaturehood as such? I would incline to defend the second option because of one striking theological observation, namely that the unknowability of man by himself (entailing the paradox and the sense of the autonomy of nature in him) is part of his Divine image. The fact that human nature is unknowable follows from its being an image and likeness of God, that is of that One Who is un-

\footnotetext{
10 Anxiety as a modus of the human existence was indirectly introduced in the context of the paradox by J.-P. Sartre and M. Heidegger.
}

knowable. A classical excerpt from patristic texts is that one of Gregory of Nyssa: "Since the nature of our mind, which is the likeness of the Creator, evades our knowledge, it has an accurate resemblance to the superior nature, figuring by its own unknowableness the incomprehensible Nature." 11 This entails that any attempted resolution of the paradox of subjectivity, as a search for the answer to the question "What is man?", qualifies such an attempt (in which man defines himself in terms of something which is less than God) as a distortion of the Divine image ${ }^{12}$. One can suggest that for the first man the question of "What is man?" did not exist in the same form as it is posed by us because of his union with God, as following God, keeping him free form anxiety of existence as creaturehood. In this case the event of the Fall can be characterized as the loss of the primordial "privilege of unknowing" and the lapse in the state of anxiety and homelessness in the world. Then the paradox (as an encapsulated "response" to the question "What is man?") explicates in a positive fashion the essence of the ambivalence of the human condition: it exists subject to the physical conditions of the world, but yet in the Divine image, that is in communion (not union!) with God. Then the question is: what is meant by evil in Yanaras' reformulation of the paradox? Since the assertion of unknowability of man is based, de facto, on a premise that he cannot create himself whilst, as a creature, holds the Divine image, the Fall can mean only a change of attitude to this inherent creaturely condition. In this case that evil to which Yannaras refers is related not to ontology of the created world, but to evil in man as the loss of the privilege of being in union with all creation

\footnotetext{
${ }^{11}$ Gregory of Nyssa, De hominis opificio [ET: (Schaff, Wace, 1996: 397). See on the unknowability of man an article (Marion, 2005), as well as a chapter from (Marion, 2010: 21-86).

12 J.-L. Marion in his (Marion, 2010: 41), quotes a passage from St Augustine's De Trinitate 10.5.7, in which, as Marion claims, a phenomenology of $\sin$ is represented through describing the human soul as turning away form God, "slithering and sliding down into less and less, which is imagined to be more and more". What is implied by this, is that any attempt of man to define himself on the basis of the human only is tantamount of denying life as the gift of that other than man, that is God, through resemblance with whom man resembles himself, and thus is only capable of defining himself.
} 
and God, resulting in his separation from the world and seeing it just as a medium of necessity and slavery, an obstacle in man's ambition for transcendence. In this sense the drama of the paradox, as well as the tension between science and theology, represent such an attitude to the sense of existence in which the basic condition of creaturehood (as a premise for being in communion with God-Creator) is forgotten. This makes it possible to treat Yannaras's interpretation of the paradox in terms of evil in a moral, but not ontological sense, explicated in similarity with those moral divisions in creation which were at the center of Maximus the Confessor's theology of deification as mediation between these divisions and, ultimately, mediation between the created and uncreated, between the world and God. Seen in this perspective, we argue, that the paradox explicates the basic predicament of the human condition as being a creature in communion with God. But, as we will discuss below, it is this predicament that paves the way for man's deification: to be deified, one must be created.

If the conditions of "evil" in Yannaras's sense correspond to the moral tensions related to the apprehension of the world, and man's inability to comprehend its facticity through the corporeal cognitive faculties, one can argue that the sciences help humanity to adapt to the conditions of "evil" in man himself, that is their primary task is to articulate, although indirectly, particular aspects of this "evil". One needs to see "evil" in order to develop an impetus for transcending its conditions. In fact, even to articulate the ambivalence in the human condition as "evil", one needs grace, as that move which positions "evil" in man beyond his natural condition. In view of this one reasonably comes back to the question of the sense of the dialogue between theology and science. Science articulates the conditions of "evil" in man although silently, not giving any moral judgment on whether nature (as being recapitulated in man) is good or bad for humanity. The moral judgment comes from theology which contrasts the ends of nature with the ends of humanity and which Yanaras described as the "autonomy of nature [that] we human beings see a challenging 'absurdity' (a violation of our own rational conception of meaning in the world)" (Yannaras, 2012: 16). In his desire to subordinate the ends of nature to the ends of himself, man exercises his archetypical "likeness" to God by knowing and judging things according to his free will. ${ }^{13}$ However, man's actual incapacity to transform nature and first of all his own nature in the manner of its creator, is determined by the fact of creaturehood. Correspondingly, that notion of "evil" which is invoked in Yanaras's quote, can be treated as a certain misuse of the Divine image in man who attempts to tame the ends of nature (in order to define himself) not through his privilege of creaturely communion with God, but through his illusion of the unlimited power of controlling the material world through reason. This ambition of man is his moral problem related to the oblivion of the fact that his privilege of the Divine image is the result of otherness with respect to God, that is creaturehood in communion.

The overcoming of this "evil" in man, that is mediation between moral tensions between parts and aspects of creation in man himself, cannot be done metaphysically, that is no philosophical concept is possible which would resolve the riddle of man or without referring it to the theology of creation. The sense of creaturehood arrives only through grace in communion, which de facto means existential transcendence. The possible overcoming of the difference between the human ends and the ends of nature can only be seen in terms of soteriological purposiveness, avoiding any ontological reference either to the natural state of man, or to any particular modus of the natural in the world, which would allegedly manifest the achievement of such a purpose. The theology of Maximus the Confessor on man's mediation between moral tensions (divisions) in creation always warned its readers that no ontological bridge between creation and its cre-

\footnotetext{
13 The analogy comes from St. Maximus the Confessor's discussion on whether God knows created things according to their nature. His answer is negative: God knows things according to his will: “....he neither knows sensible things sensibly nor intellectual things intellectually. For it is out of question that the one who is beyond existent things should know things in the manner proper to beings. But we say that God knows existent things as the products of his own acts of will..." (Ambigua, 7, PG 91, 1085B) [ET: (Blowers, Wilken, 2003: 61-62)].
} 
ator will be possible through mediation and deification. In other words, the ends of nature will never be subordinated to the ends of humanity on the ontological level. On the moral level, the ends of man and the ends of nature can be reconciled through such a transfiguration of the spiritual insight in man that will ease the drama of nature's autonomy and make humanity free not from the conditions of nature, but from anxiety of creaturehood.

One can summarize that the unknowabililty of man by himself, expressed through the paradox of subjectivity, encapsulates the essence of the moral division in man between his limited created position in the physical world and his intellectual and spiritual capacity to transcend the world and to long for the unconditional and eternal. The dialogue between theology and science then represents a future explication of man's drama of creaturehood providing us with the open-ended hermeneutics of man's created existence in communion with God.

\section{The Unknowability}

\section{of Man as Oblivion of Origins}

The paradox of subjectivity, or the mystery of the ambivalent position of man in the universe can be considered in the context of the issue of beginnings. One implies the beginning of that consciousness in man which is responsible for man's reflection upon its standing in front of the universe in the conditions of the paradox. The reflecting consciousness always slides back to the mystery of its beginning because the hidden nature of this beginning is the very simple and primordial manifestation of man's unknowability by himself. ${ }^{14}$ Man, although not being able to explicate its own beginning, always faces this beginning as a problem that is implicitly present in his consciousness as that which cannot be "looked" at; as that which is inescapable from the very fabric of the human condition and that which can hardly be distinguished from experience of life. This situation is explicated in a phenomenological treatment of birth, understood as coming

${ }^{14}$ C.f. the already quoted passage from (Merleau-Ponty, 1962: 453). into existence of hypostatic human beings, that is persons.

The problem is that I can experience my birth $^{15}$ only through its delayed consequences: I did not see my birth and I must rely on the account of my parents or other witnesses in order to attempt to grasp my birth as that occurrence which affects me through all my life, but I will never be able to reconstitute this event as a phenomenon. The phenomenon of birth gives itself without showing itself because it comes to pass as an event, that is something without foundation, ground, as origin but which is non-originary. ${ }^{16}$ The exceptional status of this event follows from the fact that birth gives itself together with that, that it gives me to myself. This is a mechanism how my birth phenomenalises itself, for without this giving me to myself I would not be able to realise that it is me who is affected by birth. The phenomenon of birth thus exemplifies the condition for any phenomenon: the possibility of phenomenalisation of all things lies in the extent by which it gives itself: the phenomenon of birth is the first phenomenon which initiates the possibility of receiving all other phenomena. The phenomenon of birth as a phenomenon par excellence, not being reducible to any preceding causes and being incommunicable and indemonstrable, forms that excess in human perception of life which is always allows for unpredictable future, for an indefinite series of commentaries and insights on the sense of this birth which extends forward in time while being interpreted retrospectively. Not being a phenomenon given to myself, I always experience an intention to look at birth as a phenomenon which initiated me, my identity, my spiritual growth, ultimately my hypostatic uniqueness. Birth as an existential premise is always silently encoded in all my actions, which attempt to reconstitute it in order to come to terms with the fact that I was born without my consent and can do nothing about it. In a way, my birth can be seen as the never-ending continuation of my experience of life, but it is

\footnotetext{
${ }^{15}$ For the purposes of simplicity we use first person language in this section.

${ }^{16}$ See on phenomenology of birth (Marion, 2003), as well as his (Marion, 2002: 41-44). See also (Romano, 1998: 95-112), and (Henry, 2003: 123-42).
} 
still inaccessible as a phenomenon to my direct gaze. My appropriation of birth is always delayed because any retrospective reflection contains as its basic element a condition of a delay: delay between the occurrence of my birth and innumerable intuitions of its meaning. In this sense me as an original being, does not have an originary origin, that is a metaphysical ground to which I can refer in order to deduce the occurrence of my birth from a chain of the worldly events. In fact, the very idea of a possibility of grounding my birth in the chain of such events signifies a fundamental reduction or deprivation of the phenomenality of birth of its excessive primordiality. It is exactly because my birth is in the foundation of all derivative intentions to construct a chain of historical or cosmological transformations, which as antecedents would conclude in my birth, that all articulations are overwhelmed initially and irreducibly by the intuition of this incomprehensible and indemonstrable event of birth.

How then can my birth as a phenomenon, while not showing itself, affect me radically in the sense that it produces my unique existence? How can the origin of myself, which is present in all following events of my life show itself in such a way that, effectively, it is indemonstrable? The answer to these questions comes from the realisation that this showing has an "eschatological" character because the past of my birth is being shown to me only through its anticipation as directed to the future. My birth has sense only as an "event" which phenomenalises itself by endowing me with future. Being an indemonstrable phenomenon birth reveals itself as an "event" that was never present to me in orders of "presence in presence" and always already imbued with the qualities of the having passed, but never irrelevant for the present and outdated. But even in this "eschatological phenomenalisation" my birth does not allow any demonstrability in a sense of communication: my birth for me is an event which cannot be grasped as a fact and correspondingly described in rubrics of thought and demonstrated, being irreproducible and surpassing any expectation and prediction.

The event of birth (if one regards it as coming-into-being of persons) as an event is not ac- countable on the level of sufficient conditions of its happening: its outcome is unpredictable and unforeseeable: given the normal physical conditions birth (conception) might not happen at all. However, the necessary conditions for this event to happen lie in the sphere of what preceded it, the physical plan. In this sense, in spite of its sporadic and unique character an event of birth as physical incarnation contains in itself that something which made the happening of this event possible. And when one says that birth gives itself in an unmediated and indemonstrable way, that is not to say that it does not contain in itself and does not manifest the hidden conditions for it to take place. These conditions come with birth and follow birth in the same unmediated and indemonstrable way. This means that in no way can I treat myself as an absolute beginning. I can oversee the limits of my origin and look objectively at it, that is to formulate for myself the necessary conditions which made it possible. My personal story can easily be extended to that "before" which lies in the foundation of my incarnation not only on the level of my parents as a biological species, but that "before and out there" which make it possible for life to exist at all. One means here physical conditions and ultimately the universe. Thus, my act of birth entails not only an unbreakable communion with my parents but an unbreakable communion with the universe where I was born and which is an implicit premise of the very possibility of my articulations with regard to both my birth and the universe as a whole. I did not choose the universe where to be born; the universe then is mine in an absolute sense. I cannot disregard the universe in my life because its presence is implanted in my birth: I am in communion with the universe from the very moment of inception of my body and consciousness.

The phenomenological concealment of the sense of birth as coming of man into existence makes this unique and personal existence incomprehensible, thus contributing to the radical unknowability of man by himself. Since the paradox of subjectivity in its philosophically articulated form is possible only for persons, the unknowability of man's personhood cascades toward the incomprehensibility of con- 
tingent facticity of the paradox itself. Since the event of birth endows man with a future, so that birth's explication goes on continuously as a process directed to the future, the hermeneutics of the paradox as an inherent feature of the human condition goes on endlessly. This explication includes the dialogue between theology and science which, as an activity directed to the future, contributes to the elucidation of the sense of birth as being created.

\section{From the Paradox of Subjectivity}

to the incarnational archetype:

the sense of the dialogue

as it is seen theologically

The approach to the question "What is man?" through the notion of communion receives its Biblical justification through the answer which God gives to Moses "I will be with you" (Exodus, 3:12). Paraphrasing, it is that who can say "I am who I am" (Exodus, 3.14) that tells to Moses that he will be with him. The whole essence of the question "Who am I?" as a concrete incarnation of the question "What is man?" entails, through the encounter with God, the answer which is not a direct response on that which is asked, but an indication that the implied sense of the response can only be given via an invitation of man into God's midst through the way of life. Communion is thus following the same imperative of God "I will be with you" on the side of man: "I will be with You by following You". By accepting God's communion man does not receive any answer on what he can or cannot know, what he ought or does not owe to do, what he may or may not hope for: thus he does not receive an answer to the question of "What is man?" as it was formulated by Kant. For God indicates to man that this question cannot be addressed and responded in abstraction simply because without communion with God it does not have sense and cannot be clarified. "Man is man only in communion with God" means that God offers man the way, which is man's history as the endowing him by the future. There is no being of man as such, devoid of the inaugural event of communion with God enabling man to have future, that is life. In other words, the "knowledge" of man by himself as such turns out to be the unfolding of his history towards that for which this history was created: man receives the sense of his telos formulated not in terms of those potentialities which are implied in the three Kant's questions, but through the definition of communion. It is only by following this God-given (through communion) purpose that man can indefinitely unfold and constitute the sense of its own existence knowing in advance that the ultimate union with God, phrased theologically as deification, will yet leave untouched an inerasable difference (diaphora) between a creature and the Creator. It is a dedication to this telos that releases man from the incessant idolatry of his images of himself, thus effectively removing all dramatism of the unanswerable nature of the question "What is man?", through which God releases man from any search for rootedness in the rubrics of the world by constantly pointing to him that while being in the world, man is not of the world (C.f., e.g., (Berdyaev, 1944, 94-95)). Man's anxiety of his contingence and homelessness in being, entailing the question of "What is man?", is intended to be replaced by offering home in God's midst, that is through being introduced to communion with God, who will be with him on all his ways. ${ }^{17}$

Then the refusal of following God, which meta-historically associated with the Fall, meant that man imagined that he can attain to himself by choosing to resemble something less than God. This is rather a paradoxical situation: to be man in communion with God is to remain in the conditions when man's Divine Image is detected, but not defined. If man attempts to define himself in some metaphysical terms pertaining to the world, that is if he denigrates his existence from the transcendent

\footnotetext{
17 A similar thought was expressed by V. Nesmelov: "Man aspires not only to the explanation of his situation in the world, but also to knowledge of that way through which he could indeed overcome this situation... To reach knowledge of the eternal mystery of being means the same as to, de facto, remove this mystery in being, that is to produce the true way for accomplishment by man of his destiny in the world and to give him true possibility for the accomplishment of this destiny. It is about this way and this possibility that Christian teaching tells man. It communicates to man that knowledge without which man cannot manage, but which he, unfortunately, cannot create" (Nesmelov, 1905: 418).
} 
communion to some immanent attribution, he effectively commits $\sin$ because he co-relates his humanity to something which is less than God. By not following God and introducing into its own definition something less than God, man predisposes himself to despair and homelessness in being because there is nothing in being which gives man a dwelling place and the comfort of reciprocity. ${ }^{18}$

However, as the Bible teaches us, the invitation to communion with God, in order to ease the feeling of despair and anxiety, does not find a straightforward response in man: it represents an existential difficulty, because communion transcends the limits of the empirical, which is accessible to the senses and logical thinking. Certainly, there always was a temptation to treat the idea of communion as an abstract ethical ideal leading to a sort of religious humanism. In reality, this invitation to communion never implied any abstract teaching on how to answer basic questions, previously quoted from Kant. It implied to see God in creation and hence to be in communion with him. This "did not prevent men from wallowing in error" (Athanasius, 1996: 42), so that the invitation to communion, not recognised by men, was reactivated through the descent of God towards man when God assumed reality of the

\footnotetext{
18 As a corollary to what we have discussed on the paradox of subjectivity, it turns out to be that any possible overcoming of the paradox of subjectivity would correspond to the diminution of the human (as being in communion but in the conditions of unknowability) in man, that is an imminent spiritual lapse into the state of deprivation of communion. However here is an intrinsic counter argument made by the same consciousness which attempts to resolve the ambiguity in the paradox. This argument is simple: the facticity of consciousness precedes any particular modus of reflection upon the ambiguity of man in the universe. This means that the resolution of the paradox (as finding a metaphysical ground for it) is impossible on the grounds of its contingent facticity that enters any human life as an event which saturates intuition and blocks its discursive apprehension. Hence the language of resolving (or overcoming) the paradox becomes irrelevant. The intended "overcoming" can be posited as a formal purpose, without implying that the actual achievement of this purpose has any metaphysical sense, as if man would find the ultimate source of this paradox (its own explication) in the world. As a result, one can conclude that the knowing of the world in the conditions of the paradox, when this paradox itself becomes a purpose of explanation, represents a purposeful activity where the purpose is only formal (See our comment on the idea of formal purposiveness in ref. 4 )
}

human flesh. This became God's self-response to his longstanding invitation to men to be in communion.

On the one hand God's descent to the poverty and miserableness of the human condition, entering friendship with the wicked and sinful, brought nothing new to man in terms of its own explanation. The vulnerable condition of the human affairs in the world with all horror and atrocities of the humans with respect to themselves, was not explained and healed away. Christ himself, by being crucified and passing through the brutal attitude of humans to humans, did not imply to teach them from the Cross on what is man. He did not attempt to teach of man along the lines of the Greek ideal of beauty and kindness. He rather confirmed to them through his witness to the Father that they "do not know what they do" (Lk 23:34). By rephrasing a response to the Kantian question, Christ demonstrated to man that without receiving Christ as the Son God, and as the Son of Man, "man does not know what to do, and what to hope for, he cannot avoid despair and uncertainty of not being able to approach the mystery of the his existence." Through his parables, Christ inaugurated the Kingdom of God, which was available to all, not only to those ideal men of the Greek philosophy. For anxiety and despair, groundlessness and non-attunement to the world, expressed through the the paradox (as an implicit longing for immortality), can be healed in man himself only through abandoning the idea of finding its own foundation in that "substance" of the world which, in spite of being created by God, yet is in a state of indifference to man and his affairs, a state which was described above as a primary "evil" (Yannaras, 2012: 16). Being a creature, man cannot receive any hope of elucidating his condition from a creature which is not hypostatic. However, man can confess unconditional love by imitating God who created the world with no hope of reciprocal love from the world. But to exercise such a love man ought to follow his archetype through God's promise of being in communion with man. In this sense the Kantian questions received practical (not abstract philosophical) answers explicat- 
ing the sense of the offered communion: "As an image of God, man cannot know himself. He can know things of the world only in the delimiters of his own unknowability. Correspondingly to avoid anxiety of this unknowabilty man ought to follow Christ (= to be in history) in order to see the world through "his eyes", where the chasm between the uncreated and created was removed through the Incarnation of the Son 'begotten before all ages'. Only in this case man may hope for the union with God in his Kingdom, but without explication of the miracle of its own creation". Communion thus becomes such a change in the tropos (the way) of existence, when the world loses its sense of a hostile terrain and the source of "evil" (where man is crushed under the weight of astronomical facts (Marcel, 1940: 32). This change invokes (in Pascal's manner) man's understanding that it is the universe that is capable of killing him, and that the universe itself does not understand this (Pascal, 1959: 78, 39).

Christ, being fully human, experienced the same predicaments as all created men, but unlike all men, he knew that coping with these predicaments proceeded from his being the Son of God. The Son of God enhypostasised himself in the conditions of the physical world and, as being fully human, he knew what it meant to be a creature and he transferred to humanity knowledge of this. The key point to the manifestation of Christ's creaturehood was his Crucifixion that showed the whole scale tragedy of being subjected to the law of death. The way to be "man in communion with God" is to follow Christ through his life in the created human condition and comprehending the whole universe through his Incarnation, Crucifixion, Resurrection, Ascension and ever being on the right hand of the Father. The major point here is experience of being created in the conditions of communion, or to be chained to the physical world whilst longing for freedom from the conditioned (and immortality) on the grounds of man's archetype in Christ. Thus, the human predicament expressed in the paradox of subjectivity receives its elucidation from the Christ-event, being the only possible theological reference in the hermeneutics of the ambivalent created condition of humanity.
In spite of Christ's moral teaching through centuries of the recent history, the Incarnation of God is not an accidental event which happened in order to heal human faults (for example, human inability to see the creator through creation $^{19}$, thus not following God). As that part of creation which has been envisioned by God from the beginning, the human predicament of the ambivalent existence in the universe was implanted in the very logic of creation by confirming once again that the main delimiter in answering the question "What is man?" proceeds from his creaturehood. Man cannot answer the question "What is man?" because he cannot create himself. By understanding this he is predisposed to communion and acquisition of Grace that confirms that man is not only a natural being, but a Divine image.

And it is through science, which is particular modus of the Divine image in man, that man understands the dimensions of his created condition not from the side of the negative connotations of the paradox of subjectivity, but, in fact, related to the whole logic of creation. It is science that makes possible to understand that it is the descent of God into the universe that predetermines the contingent facticity of the universe which accommodates man. For the Word-Logos of God to assume human flesh, there must be this flesh. Since modern physics and biology are clear with respect to the necessary conditions of existence of such a flesh requiring at least ten billion years of cosmological evolution, it seems evident that for the Incarnation to take place the necessary physical conditions must have been fulfilled. To have a body of Christ and his Mother (Virgin Mary) the universe must have had from the beginning the propensity to produce them. Correspondingly the ontological aspect of the Incarnation ${ }^{20}$ is always present in the reversed history of the universe as it is described in modern cosmology. ${ }^{21} \mathrm{Ac}-$

\footnotetext{
19 See, for example Athanasius. In On the Incarnation, 3: 11, 12 (Athanasius, 1996).

20 The ontological view of the Incarnation can be seen through a modern theological development called "deep Incarnation" (Gregersen, 2001).

${ }^{21}$ These conditions are summarised in various versions of the Anthropic Principle (AP), which detects consubstantiality of the physical stuff of the universe and human corporeal beings.
} 
cording to T. Torrance the whole surrounding world, being created freely in the act of Love between the Persons of the Holy Trinity, exhibits contingent necessity related to its physical structure, its space and temporal span, encoding the motive of the Incarnation (and hence man) in the fabric of creation (Torrance, 1998). These observations change a stance on the position of man in the cosmos, releasing him from the mediocrity and insignificance of its physical existence. The question "What is man?" receives its elucidation through adoption of a new vision that the very existence of man is "implanted" in the fabric of creation, whose logic presupposes bringing creation to communion with God through man. If the motive of the Incarnation is linked to the logic of creation, man as a particular segment of creation becomes inextricably intertwined with the rest of creation. Since the actual historical Incarnation happens in the midst of the human subset of the universe (recapitulating the universe on the level of consubstantiality and epistemological acquisition), its proper sense can be directly related to the constitution and meaning of the cosmos, in which humanity itself is not positioned anymore on the periphery of the created universe, but in its centre as immanent intentionality of creation. ${ }^{22}$ However one must not treat the Incarnation and the very existence of intelligent humanity as metaphysically predetermined in the creation. One can only assert that; indeed, the logic of creation contained the necessary conditions for existence of intelligence and hence the Incarnation. The sufficient conditions for both, human intelligence or the Incarnation can only be detected through the actual happening of the Incarnation, thus providing us with their transcendent references (paradigmatic). The sufficient conditions for the Incarnation are not part of the underlying ontology of the world and here the revelational aspect of the Incarnation that enters the discussion framed in terms of the inauguration of the Kingdom

\footnotetext{
22 Maximus the Confessor, for example, refers to man, created in the image of God, as a key to understanding creation in his process of divinization when he may elevate it to the supreme level of its full soteriological comprehension. See e.g. (Thunberg, 1985: 76) referring to Maximus' Questions to Thalassius 35 .
}

of God. This is to say that the Incarnation is not part of the natural conditions in the world. Even if the world was created by God in order to attain the union with God, it is humanity which is granted the means of such an attainment through a special call. The possibility of such an attainment effectively contributes to the definition of man: only in communion with God man becomes "himself." 23 In this sense man, in spite of being consubstantial to the visible creation ${ }^{24}$ and having solidarity with it, is a special creation whose essence requires grace, and the mechanism of acquiring this grace proceeds through the Incarnation. Then one can see that the proper theological input in the dialogue of theology with the sciences originates exactly in the archetypical predisposition (endowed by the incarnate Christ) of relating the visible universe to its transcendent foundation, given to humanity through the grace of the "giver of life." If one generalises this, the dialogue between theology and science, as co-existence of different attitudes to the created world, has its archetype in the Incarnate Christ for whom the predicament of the dialogue did not exist because this dialogue was Christ's own creation in the same sense as the world and its scientific exploration were created by him. The difference in attitude to the world (present in theology and science) was introduced by Christ in order to teach man about the meaning of creaturehood in the conditions of communion with God. Being in human flesh, Christ as the Logos-creator, had to hold the image of the physically disjoint universe in one single consciousness as an intelligible (noetic) entity. Thus, the unity of the created world, being split in itself as the sensible and intelligible, becomes the pivotal indication of the sense of the created. This split in representation of man by himself (as the composite unity of the empirical and intel-

\footnotetext{
${ }^{23}$ As was expressed by J. Zizioulas, one cannot identify man through a syllogistic formula "man=man" which, if one follows a philosophical logic, contains a pointer beyond itself towards the definition of man as "man=man-in-communionwith-God" (Zizioulas, 2006: 248).

${ }^{24}$ According to modern cosmology human body, consisting of atoms, effectively interacts only with $4 \%$ of all matter of the universe, remaining de facto non-consubstantial to the rest $96 \%$ of the allegedly existing Dark Energy and Dark Matter.
} 
ligible) indicated in the paradox of subjectivity cascades towards the split between science and theology, pointing towards a simple fact that neither empirical nor theoretical knowledge of the universe can receive any justification of their contingent facticity if the ultimate source if this facticity is not sought in the logic of creation. Thus, the dialogue between theology and science can be treated as an outward manifestation of the radical createdness of humanity wrestling with its own incapacity to control its own ends, as well the ends of the world. It is not difficult to guess that such a dialogue is an open-ended enterprise, having no metaphysical accomplishment and hence having sense only as contributing to the infinite hermeneutics of the created human condition.

One can be tempted to link the unknowability of man by himself, and the paradox of subjectivity, not to the issue of creaturehood, but to the conditions of the Fall as if the ambivalence in the human condition formulated in the paradox proceeds from the loss of memory of "all in all" (Eph. 4:6) in the post-lapserian state. Correspondingly, the resolution of the paradox could be associated with the acquiring back the state of the first man Adam. However, this cannot be true, because the first man was also created and his knowledge of "all in all", implanted in his Divine likeness, did not guarantee him being able to reproduce himself in a manner he was created by God. The crucial moment in explicating man's unknowability is Christ who, by being God and fully human, elucidates to man the sense of man's created condition, the sense which, as such, was obscured by the Fall. The traditional link between the Fall and the Incarnation is that the latter is treated as a redeeming act of God towards saving the transgressing humanity. However, Orthodox theology points towards a connection between creation and the Incarnation, as being, de facto, a necessary and sufficient condition for the created to be brought to union with God. In other words, the motive of the Incarnation is linked to the aim of creation. ${ }^{25}$ According

\footnotetext{
${ }^{25}$ According to G. Florovsky, "It seems that the 'hypothesis' of an Incarnation apart from the Fall is at least permissible in the system of Orthodox theology and fits as well enough in the mainstream of Patristic teaching. In An adequate answer to
}

to Maximus the Confessor, the creation of the world contained the goal for which all things were created: "For it is for Christ, that is, for the Christic mystery, that all time and all that is in time has received in Christ its beginning and its end." ${ }^{26}$ It is in this sense that the motives of creation and the Incarnation are inextricably intertwined and this, theologically (and in addition to the cosmological findings), points to the fact that the phenomenon of man is intrinsically linked to the motive of creation. Man was created in the universe, and because of its createdness he experiences his Divine image through unknowabililty and ambivalence of existence. From here one can conclude that the dichotomy between theology and science is thus an inevitable characteristic of man's creaturehood, so that the sought reconciliation of theology and science is impossible in the human condition to the same extent as the overcoming of the ontological (not moral) division between creation and God in the process of deification.

By linking the motive of the Incarnation to the intrinsic logic of creation of the world by God, Orthodox theology extends the scope of the Incarnation beyond the opposition Fall-Redemption, towards a more wider span of the plan of salvation as related to the deification of man and bringing the whole creation to the union with God. The lesser arch of the Fall-Redemption becomes a tool in restoring the greater arch Creation-Deification. ${ }^{27} \mathrm{~A}$ famous phrase

the 'motive' of the Incarnation can be given only in the context of the general doctrine of Creation." (Florovsky, 1976: 170) (Emphasis added) (The discussion of "Cur Deus Homo?" has never been a part of the canonical corpus of Orthodox literature and constituted, in words of G. Florovsky, a theologumenon (theological opinion)).

26 Maximus the Confessor. In Questions to Thalassius, 60.

27 (Louth, 2007: 34-35). In this sense the conditioning of the Incarnation by the human concerns would be a mistake: "Christ is not a mere event or happening in history. The incarnation of the divine Logos was not a simple consequence of the victory of the devil over man... The union of the divine and the human natures took place because it fulfilled the eternal will of God" (Nellas, 1997: 37) (emphasis added)), so that it "...showed us that this was why we were created, and that this was God's good purpose concerning us from before ages, a purpose which was realised through the introduction of another, newer mode" (Maximus the Confessor, Ambigua, PG 91: 1097C [ET: (Constas, 2014: 131-133)], that is the entrance of "the incorporeal and incorruptible and immaterial Word of God [into] our world" (Athanasius, 1996: 33). 
from Athanasius that God "assumed humanity that we might be made God" 28 implies that humanity, being created, has a potential to be in union with God (not based in the natural laws related to creation). One can say stronger that creaturely modus of existence becomes unavoidable for the very possibility of deification. Correspondingly, if God's plan "consists in deification of the created world" (some parts of which imply salvation), the plausibility of the plan of deification is rooted in the fact that man is ontologically united with the created nature. Man is the "microcosm who resumes, condenses, recapitulates in himself the degrees of the created being and because of this he can know the universe from within" (Clément, 1976: 90). In this sense Orthodox theology links the Incarnation to humanity as that subset of the created universe which is capable of conducting a mediating role in overcoming moral tensions between different parts of creation, creation and God. ${ }^{29}$ The mediation between moral divisions in creation explicates the sense of being created and the delimiters of deification: the union with God through these mediations does not remove the basic ontological difference ( $d i$ aphora) between the world and God thus not removing the riddle of man, retaining his basic definition as being a creature in communion with God.

The reader may be puzzled by such a paradoxical situation: indeed, if one talks about deification as the union with God, and deification is possible through the Incarnation, why man cannot achieve through this deification that state that was pertaining to Christ the Incarnate? The answer is: Christ hypostatically remained the Logos of God and was controlling his enhypostasisation in Jesus by being able to explicate its own human, that is created nature. However, this is not given to man, so that the Incarnation remains an archetype of the human (Divine image/physical flesh = uncreated/created) predicament. At the same time the Incarnation brings a kind of a natural division in our understanding of communion. According to Maximus the Confessor the In-

\footnotetext{
${ }^{28}$ Athanasius. In On the Incarnation 54 (Athanasiius, 1996: 93).

${ }^{29}$ See, for example (Thunberg, 1995: 387-427).
}

carnation brought the division in the temporal span of evolution of the universe onto two fundamentally different aeons: “...God wisely divided 'the ages' between those intended for God to become human, and those intended for humanity to become divine." 30 This excludes a possibility of treating the movement from creation to deification through the Incarnation as a "natural process" inherent in the fabric of creation. On the one hand created things participate in God through the fact of their existence, that is through "being in communion." However, when Maximus enquires in the human capacity of deification, he stresses that it does not belong to man's natural capacity. ${ }^{31} \mathrm{By}$ separating the aeons before and after the Incarnation Maximus makes a difference between the participation in God which is bestowed to man by creation and that participation which is bestowed by deification. Said differently, the aeon after the Incarnation corresponds to the movement of man to God, whose very possibility was effected by the Incarnation, and whose actual exercise demands not only communion through existence, but communion through grace. Grace is not implanted in the natural conditions of existence, but is bestowed by God on the grounds of man's personal extent of perfection. ${ }^{32}$ It is this grace that makes possible for man to realise his ambivalence in the universe originating in creaturehood. It is this grace that makes possible to enquire in the contingent facticity of the sciences thus initiating their dialogue with theology. It is this grace that makes theology possible as that constituent of knowledge that explicates the sense of the created humanity.

\footnotetext{
${ }^{30}$ Maximus the Confessor, Ad Talassium 22 [ET: (Blowers, Wilken, 2003: 115)] This point sheds the light on the inclusion of the lesser arch of Fall-Redemption into the greater one of Creation-Deification as the different degrees of participation in God.

31 “...what takes place would no longer be marvellous if divinization occurred simply in accordance with the receptive capacity of nature" (Maximus the Confessor, Ambigua 20 [ET: (Constas, 2104: 411)].

${ }^{32}$ L. Thunberg with reference to Maximus asserts: "There is in man no natural power that can deify him, but there exists on the other hand a reciprocal relationship between God and man that permits him to become deified to the degree in which the effects of the Incarnation are conferred on him" (Thunberg, 1985: 55).
} 


\section{Conclusion}

The Dialogue between Theology and Science as open-ended hermeneutics of the human condition

The duality in hermeneutics of the subject which is transpiring through the dialogue between theology and science receives its elucidation from the basic feature of man related to its creaturehood: man exists through communion with God by the fact of its createdness, but he does not "possess" himself entirely in the world even in tendency, because the conditions of communion through grace are not part of the world. Indeed, by detecting his ambivalent position in the world (the paradox of subjectivity), man discovers himself in the conditions of an intellectual impasse, that is incapacity of understanding the contingent facticity of such a paradox as the delimiter of his embodied consciousness. Through attempts to find the metaphysical grounds for himself, man produces instead infinite hermeneutics of its own predicament thus sensing that the very means of interrogation of himself by himself cannot be existentially clarified. Here, an inerasable Divine image in man invokes the latter to seek for God's help and thus following God, that God who once descended in the world to teach man about his creaturehood in order to be deified. How all this relates to the problem of this paper about the dialogue between theology and science?

The sciences implicitly articulate the outward sense of existence in communion (that is being created) through their very contingent facticity, that is through the fact that they are. The underlying foundation of the sciences is man, whose sense, nevertheless cannot be completely explicated either by the sciences or by philosophy. The sciences function in the conditions man's unknowability by himself. Theology encounters the sciences (and philosophy) in order to release man from an intellectual impasse of unknowability and to invite him to learn from his archetype in Christ that in spite of his creaturehood, he remains in communion and has a potential to achieve the union with God for the sake of understanding that the unknowability and paradox remain the basic theological delimiters in man's self-awareness of his creaturehood.

This brings us to the final conclusion that the dialogue between theology and science represents open-ended hermeneutics of the created human condition. The discourse of the paradox of subjectivity and that of oblivion of origins (phenomenology of birth) provide the delimiters for any of such hermeneutics. Since the riddle of unknowability of man by himself cannot be resolved in terms of metaphysical concepts, cascading down towards the irresolvable nature of the paradox, the dialogue between science and theology cannot hope to have any material goal as its accomplishment. The moral tension between man's created condition and its Divine image, as well as a capacity of receiving grace of deification, retains the dialogue active and alive always and forever, just confirming a simple existential truth that both - science and theology originate in one and the same man, created in communion with God, but living in a moral tension between the sense of his created limitedness and graceful longing for the unconditional and immortal.

\section{References}

Athanasius (1996). On the Incarnation. Crestwood: St Vladimir's Seminary Press.

Berdyaev, N. (1944). Slavery and Freedom. London: Centenary.

Carr, B. (1998). "On the Origin, Evolution and Purpose of the Physical Universe". In Modern Cosmology and Philosophy, ed. J. Leslie. New York: Prometheus, 140-159.

Carr, D. (1999). The Paradox of Subjectivity. Oxford: Oxford University Press.

Clément, O. (1976). "Le sense de la terre" Le Christ terre des vivants. Essais théologiques spiritualite orientale, n. 17. Bégrolles-en-Mauges: Abbaye de Bellfontaine.

Florovsky, G. (1976). “Cur Deus Homo? The motive of the Incarnation”. In Creation and Redemption. The collected works of Georges Florovsky, vol. III, Belmont, Mass.: Nordland Publishing Company, 163-170. 
Frank, S. (1965). Reality and Man. New York: Taplinger.

Fromm, E. (1967). Man for Himself. An Enquiry into the Psychology of Ethics. London: Routledge and Kegan Paul.

Gregersen, N. (2001). "The Cross of Christ in and Evolutionary World", Dialog: A Journal of Theology, 40 (3), 192-207.

Gregory of Nyssa (1996). De hominis opificio [ET: On the Making of Man]. In The Nicene and Post-Nicene Fathers, ed. P. Schaff and H. Wace. Grand Rapids, MI: W. B. Eerdman Publishing Company, 5, 387-427.

Henry, M. (2003). "Phenomenology of Life", Angelaki 8(2), 100-110.

Henry, M. (2003). De la Phénoménologie. Tome I. Phénoménologie de la vie. Paris: Presses Universitaire de France.

Husserl, E. (1970). The Crisis of European Sciences and Transcendental Phenomenology. Evanston: Northwestern University Press.

Jaspers, K. (1954). Ways to Wisdom. New Haven: Yale University Press.

Kant, I. (1951). Critique of Judgement, Tr. J. H. Bernard. London: Hafner Press.

Kant, I. (1959). Critique of Practical reason and Other Works on The Theory of Ethics, Tr. T. K. Abbot. London: Longmans.

Louth, A. (2007). "The place of Theosis in Orthodox theology", in Partakes of the Divine Nature: The History and Development of Deification in the Christian Traditions, Eds. M. J. Christensen and J. A. Wittung. Madison: Fairleigh Dickinson University Press, 32-44.

Marcel, G. (1940). Du Refus a l'Invocation. Paris, Galllimard.

Marion, J.-L. (2002). In Excess. Studies of Saturated Phenomena. New York: Fordham University Press.

Marion, J.-L. (2003). "The Event, the Phenomenon and the Revealed". In Transcendence in Philosophy and Religion, ed. J.F. Faulconer, (Bloomington and Indianapolis, Indiana University Press), 87-105.

Marion, J.-L. (2005). “Mihi magna quaestio factus sum: The Privilege of Unknowing”. In The Journal of Religion 85 (1), 1-24.

Marion, J.-L. (2010). Certitudes negatives. Paris: Bernard Grasset.

Maximus the Confessor (1986). "Various Texts on Theology, the Divine Economy, and Virtue and Vice". In The Philokalia: St. Nikodimos of the Holy Mountain and St. Makarios of Corinth, Eds. G.E.H. Palmer, P. Sherrard, and K. Ware, vol. 2. London: Faber].

Maximus the Confessor (2003). Ambigua 7. ET: P.M. Blowers, R.L. Wilken, On the Cosmic Mystery of Jesus Christ. Selected Writings from St. Maximus the Confessor. Crestwood NY: St. Vladimir's Seminary Press, 45-74.

Maximus the Confessor (2003). Ad Talassium 22. ET: P.M. Blowers, R.L. Wilken. In On the cosmic mystery of Christ (Crestwood: St. Vladimir's Seminary Press, 115-118.

Maximus the Confessor, (2014). Ambigua. ET: On Difficulties in the Church Fathers. The Ambigua. 2 vols., Ed. and tr. N. Constas, Cambridge, Mass.: Harvard University Press.

Merleau-Ponty, M. (1962). Phenomenology of Perception. London: Routledge \& Kegan Paul.

Merleau-Ponty, M. (1982). Sense et Non-Sense. Evanston: Norhwestern University Press.

Moltmann, J. (1974). Man. Christian Anthropology in the Conflicts of the Present. London: SPCK.

Nagel, T. (1986). The View from Nowhere. Oxford: Oxford University Press.

Nellas, P. (1997). Deification in Christ. Orthodox Perspectives on the Nature of the Human Person. Crestwood: St. Vladimir's Seminary Press.

Nesmelov, V. (1905). The Science of Man. Kazan: Central Printing House.

Nesteruk, A. (2015). The Sense of the Universe. Minneapolis: Fortress Press.

Nesteruk, A. (2018). "Philosophical Foundations of the Dialogue between Science and Theology". In Journal of Siberian Federal University. Humanities \& Social Sciences, 11 (2), 276-298.

Pascal, B. (1959). Pensées. Selections. Tr. \& ed. Martin Jarret-Kerr. London: SCM.

Plessner, H. (1961). Conditio humana. Berlin.

Romano, C. (1998). L'événement et le monde. Paris: Presses Universitaires de France.

Scheler, M. (1994). Die Stellung Des Menschen im Kosmos. Moscow: Gnosis. 
Soloviev, V. (1989). Readings on Godmanhood. Moscow: Pravda.

Thunberg, L. (1985). Man and the Cosmos. Crestwood: St. Vladimir's Seminary Press.

Thunberg, L. (1995). Microcosm and Mediator: The Theological Anthropology of Maximus the Confessor. Chicago: Open Court.

Torrance, T. (1998). Divine and Contingent Order. Edinburgh: T\&T Clark.

Yannaras, C. (2012). The Enigma of Evil. Brookline, MA: Holy Cross Orthodox Press.

Yannaras, C. (2011). "The Church in Post-Communist Europe", The Meaning of Reality. Essays on Existence and Communion, Eros and History. Los Angeles: Sebastian Press \& Indiktos, 123-143.

Zizioulas, J. (2006). Communion and Otherness. London: T\&T Clark.

\title{
Диалог между богословием и наукой
}

\section{как нескончаемая герменевтика человеческого состояния}

\author{
A.B. Нестерук \\ Университет Портсмута \\ Великобритания, Портсмут \\ Российская христианская гуманитарная академия \\ Российская Федерация, Санкт-Петербург
}

\begin{abstract}
Аннотация. Эта статья о развитии представлений о смысле диалога между богословием и наукой в рамках феноменологической философии и ее богословского расширения, предпринятого автором в ранних работах. Автор отстаивает мнение, что причиной напряженности во взгляде на природу реальности в науке и богословии служит парадоксальное положение человека во Вселенной, являющегося, с одной стороны, объектом мира, а с другой стороны, его субъектом, т. е. артикулирующим сознанием. Поскольку, согласно современной философии, устранение двойственного положения в герменевтике субъекта невозможно, проблема фактичности человеческой субъективности как смыслообразующего центра мира приобретает богословское измерение, требующее развитие как богословия, так и философии. Показано, что желаемое преодоление непознаваемости человека самим собою (выраженной в указанном выше парадоксе), неявно подразумеваемое в попытках “объединения" науки и богословия, невозможно онтологически, но как таковое демонстрирует работу формальной целесообразности (в смысле Канта) в человеческом сознании. Отсюда вывод: диалог между богословием и наукой представляет собой целесообразную активность сознания без достижения материальной цели и тем самым вносит вклад в бесконечную герменевтику человеческого состояния.
\end{abstract}

Ключевые слова: богословие, герменевтика, диалог, наука, субъект, философия, человек, человеческое состояние.

Эта публикация стала возможной благодаря гранту «РН Философия в неопатристике: новые персонажи и новые интерпретации», предоставленному Национальным Научным Центром Польши (DEC-2018/31/B/HS/01861).

Научная специальность: 09.00.08 - философия науки и техники. 